\title{
Heterogeneity of human serum amyloid A protein
}

\author{
Five different variants from one individual demonstrated by cDNA sequence analysis
}

\author{
Alexander STEINKASSERER, Elisabeth H. WEISS, Wilhelm SCHWAEBLE and Reinhold P. LINKE* \\ Institut für Immunologie der Universität München, Goethestrasse 31, D-8000 München 2, Federal Republic of Germany
}

\begin{abstract}
Serum amyloid A (SAA), a chemically polymorphic protein, is the most sensitive marker protein of the acute phase and the precursor of reactive amyloidosis, which is characterized by deposits of amyloid A protein (AA). We investigated the variability of the SAA gene family in one individual by sequencing 11 SAA-specific clones from an acute-phase-liver cDNA library. At least five different SAA variants were deduced from six different cDNAs. The $3^{\prime}$ untranslated gene segments fall into two groups, based on nucleotide sequence and variability in length. Various nucleotide and amino acid substitutions were found predominantly in the $3^{\prime}$ portion. Some of these substitutions are unique and increase the number of SAA variants in one individual to at least five. Moreover, genomic DNA of four individuals was examined by analysis of restriction-fragment length polymorphism. Besides two conserved strongly labelled bands, additional polymorphic bands were observed, indicating isotypic and/or allotypic SAA variations. Finally, three different mRNA species were detected by Northern-blot analysis, a finding that might be of relevance for the stability of SAA transcripts.
\end{abstract}

\section{INTRODUCTION}

Amyloidosis secondary to chronic inflammations is caused by systemic deposition of degradation-resistant fibrillar proteins. These fibrils, which consist of amyloid A protein (AA), are derived from serum amyloid A protein $\left(\mathbf{S A A}_{12}\right)$ by limited proteolysis (Benditt \& Eriksen, 1977). Amyloid fibrils, including the AA type, are diagnosed as amyloid in tissue sections on the basis of their unique histochemical staining properties (Glenner, $1980 a, b)$.

In plasma, $\mathrm{SAA}_{180}$ is a molecule of $\alpha_{1}$-protein electrophoretic mobility (Levin et al., 1973) that is $180 \mathrm{kDa}$ in size (Linke et al., 1975 ) and has remarkable acute-phase properties (Gorevic et al., 1976). After denaturation a $12 \mathrm{kDa}$ molecule of $\beta$-protein electrophoretic mobility was identified and was designated SAAL. Its physicochemical and immunochemical properties differ from those of the native $\mathrm{SAA}_{180}$ molecule (Linke et al., 1975; Linke, 1980). When SAAL was found to be associated with high-density lipoprotein to form the $180 \mathrm{kDa}$ complex, it was also designated apoSAA (Benditt et al., 1982). SAA ${ }_{12}$, which is composed of 104 amino acid residues and lacks cysteine as well as carbohydrate (Parmelee et al., 1982), shows a microheterogeneity based on charge differences (Bausserman et al., 1980; Marhaug \& Husby, 1981; Skogen et al., 1986). This microheterogeneity is also present in its derivative the 6-9 $\mathrm{kDa} A A$ protein (Linke et al., 1975; Westermark, 1982).

These charge differences are assumed to be the result of chemical differences and limited fragmentation. The total number of human SAA genes and mRNAs is unclear. The amino acid sequence data obtained from human AA-type amyloid fibrils and the respective precursor proteins tend to indicate that there are more than three genes.

Comparison of published data for SAA genomic and cDNA clones points to the existence of at least three different SAA genes in humans (Sipe et al., 1985; Sack \& Lease, 1986; KluveBeckerman et al., 1986, 1988; Woo et al., 1987). Four SAA genes were found in the mouse, one being a pseudogene (Lowell et al.,
1986; Yamamoto et al., 1986, 1987). Interestingly, one SAA isotype (SAA2) is the preferred amyloid-forming precursor in mice (Meek \& Benditt, 1986).

Our present study provides strong evidence for the existence of more than three SAA genes in man: at least five different mRNAs can be deduced from the seven cDNAs isolated from one individual. Data on the variability at the genomic DNA level indicative of SAA allotypes are also presented.

Part of this study was presented at the 9th European Immunology Meeting held in Rome (Steinkasserer et al., 1988).

\section{MATERIALS AND METHODS}

\section{Identification of SAA cDNA clones}

We isolated SAA-specific cDNA clones from a human acutephase-liver cDNA expression library (Stanley \& Luzio, 1984). This expression library, which was generously provided by $\mathrm{K}$. Stanley, was screened with a human SAA-specific cDNA (pA1; Sipe et al., 1985; courtesy of Dr. J. D. Sipe) that had been labelled with [ ${ }^{32}$ P]dATP (Amersham, Braunschweig, Germany) by the polypriming method (Feinberg \& Vogelstein, 1983). After rescreening, positive clones were further characterized by restriction-enzyme mapping and sequence analysis.

\section{Sequence analysis of SAA cDNA}

After purification of plasmid DNA, the cDNA inserts were excised by $P s t I$ digestion and isolated by preparative agarose-gel electrophoresis in accordance with standard protocol (Maniatis et al., 1982). The PstI fragments were subcloned in the bacteriophage vector M13 mpl1 (Boehringer, Mannheim, Germany) and sequenced in both orientations by the dideoxy chain-termination method described by Sanger et al. (1977).

\section{Southern-blot analysis}

We investigated the organization of SAA genes in the human genome, using a $5^{\prime} \mathrm{cDNA}$ probe $\left(\mathrm{pAS}_{4}\right)$ and a $3^{\prime}$ cDNA probe

\footnotetext{
Abbreviations used: AA, amyloid A protein; SAA, serum amyloid A protein [the abbreviation SAA is used inconsistently in the literature to describe the native $180 \mathrm{kDa}$ or the denatured $12 \mathrm{kDa}$ protein SAAL/apoSAA; we differentiate between SAA and SAAL/apoSAA by adding the molecular mass as a subscript (SAA 180, SAA $_{12}$ ), when necessary].

* To whom correspondence should be addressed.

The nucleotide sequence data reported will appear in the EMBL, GenBank and DDBJ Nucleotide Sequence Databases under the accession numbers X51439, X51440, X51441, X51442 and X51443 for the cDNA clones $\mathrm{pAS}_{1}, \mathrm{pAS}_{2}, \mathrm{pAS}_{3 \alpha}, \mathrm{pAS}_{3 \beta}$ and $\mathrm{pAS}_{4}$ respectively.
} 


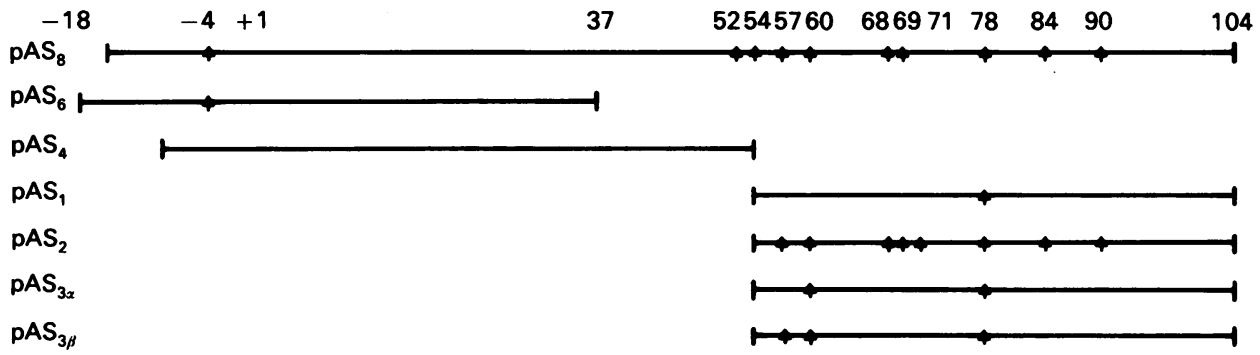

Fig. 1. Overview of different SAA cDNA clones

Shown is the coding region of each PstI insert. Numbers above the $\mathrm{pAS}_{\mathbf{8}}$ line refer to amino acid positions; arrows indicate the position of nucleic acid variations as compared with clone pAl (Sipe et al., 1985). Full-length clone pAS ${ }_{8}$ is followed by two $5^{\prime}$ clones $\left(\mathrm{pAS}_{6}\right.$ and $\left.\mathrm{pAS}_{4}\right)$ and four $3^{\prime}$ clones $\left(\mathrm{pAS}_{1}, \mathrm{pAS}_{2}, \mathrm{pAS}_{3 \alpha}\right.$ and $\left.\mathrm{pAS}_{3 \beta}\right)$. Clone $\mathrm{pAS}_{6}$ is a truncated form of clone $\mathrm{pAS}_{8}$ and ends at amino acid 37.

$\left(\mathrm{pAS}_{1}\right)$ for analysis of restriction-fragment length polymorphism. Genomic DNA from four individuals was digested with four restriction enzymes (TaqI, EcoRI, BgIII and PstI; all from Boehringer), and $10 \mu \mathrm{g}$ of each digest was separated by electrophoresis on a $0.7 \%$ agarose gel, transferred to Hybond-N nylon membrane (Amersham), and hybridized with each cDNA probe $\left(1 \times 10^{6}\right.$ c.p.m./ml) as described by Maniatis et al. $(1982)$.

The oligonucleotides $\left(\mathrm{oAS}, \mathrm{oAS}_{2}\right.$ and $\mathrm{oAS}_{8}$ ) were synthesized (cyanoethyl method) by courtesy of R. Mertz (Genzentrum Munich, Munich, Germany). Oligomer oAS $\mathrm{O}_{2}$ is specific for the translated region of clone $\mathrm{pAS}_{2}$, and oligomer $\mathrm{oAS}_{1}$ for the short 3 ' untranslated region of clone $\mathrm{pAS}_{1}$ (for sequences see Fig. 2). Hybridization conditions were established so that each oligonucleotide specifically recognized only its identical complementary sequence. Purification and hybridization of the oligonucleotides were performed as described by Geliebter et al. (1986). Oligomers were labelled with [ $\left.{ }^{32} \mathrm{P}\right] \mathrm{dATP}(3000 \mathrm{Ci} / \mathrm{mmol})$ and terminal deoxynucleotidyltransferase $(20$ units $/ 13 \mu \mathrm{l})$ to high specific radioactivity as described by Collins \& Hunsaker (1985). Specific hybridization signals were obtained with labelled oligomer $\left(1 \times 10^{6}\right.$ c.p.m. $/ \mathrm{ml}$; hybridization temperatures were for oAS $164^{\circ} \mathrm{C}$, for oAS $62^{\circ} \mathrm{C}$ and for oAS $55^{\circ} \mathrm{C}$ ) under the stringent washing conditions described by Geliebter et al. (1986). Analysis with oligonucleotides was performed on an EcoRI digest of genomic DNA.

\section{Northern-blot analysis}

The $5^{\prime}$ cDNA and $3^{\prime}$ cDNA probes were also used to analyse mRNA preparations from human acute-phase (non-neoplastic) liver tissue from a patient with hepatoma and as control a biopsy specimen from a patient with alcoholic hepatopathy without detectable acute phase. RNA was fractionated by electrophoresis on a $1.2 \%$ agarose gel and on a $6 \%$ polyacrylamide slab gel with 7 M-urea. Both were transferred to Hybond-N nylon membrane by either capillary blotting or electrotransfer, and hybridized with the radiolabelled SAA cDNA $\left(\mathrm{pAS}_{1}\right)$ and oligonucleotide probes $\mathrm{oAS}_{1}, \mathrm{oAS}_{2}$ and $\mathrm{oAS}_{8}$.

\section{RESULTS}

\section{Isolation of SAA cDNA clones}

Eleven cDNA clones were isolated by screening approx. 50000 colonies from an amplified liver cDNA library (Stanley \& Luzio, 1984) with the SAA-specific cDNA probe pA1. The expression cDNA library was prepared by subcloning cDNA Pst I fragments into the prokaryotic expression vector $\mathrm{pEX} 2$. Thus original complete cDNA sequences with an internal PstI site cannot be obtained as full-length clones but are obtained in two separate plasmids. The SAA PstI inserts ranged from $300 \mathrm{bp}$ to $700 \mathrm{bp}$. Among the 11 cDNA clones four were completely identical, yielding seven different inserts. Since clone $\mathrm{pAS}_{6}$ is a truncated form of $\mathrm{pAS}_{8}$, six different DNA clones were found. $\mathrm{pAS}_{8}$ was isolated as a full-length clone that lacks the internal PstI site. The other isolated SAA sequences contained either the $5^{\prime}$ half of the SAA gene $\left(\mathrm{pAS}_{6}\right.$ and $\left.\mathrm{pAS}_{4}\right)$ or the $3^{\prime}$ end $\left(\mathrm{pAS}_{1}, \mathrm{pAS}_{2}, \mathrm{pAS}_{3 \alpha}\right.$ and $\mathrm{pAS}_{3 \beta}$ ) (Fig. 2). Thus we have found five different $3^{\prime}$ cDNA segments, one in contiguity with the $5^{\prime}$ end $\left(\mathrm{pAS}_{8}\right)$ and four $\left(\mathrm{pAS}_{1}, \mathrm{pAS}_{2}, \mathrm{pAS}_{3 \alpha}\right.$ and $\left.\mathrm{pAS}_{3 \beta}\right)$ truncated as a consequence of the internal PstI site. Since no information is available as to which of the $5^{\prime}$ segments is connected in the transcript with which of the $3^{\prime}$ segments, the minimal number of distinct transcripts must be at least five.

\section{Sequence comparison}

All seven cDNA and the deduced polypeptide sequences are listed in Fig. 2. They show various substitutions. Two cDNA clones $\left(\mathrm{pAS}_{3 \alpha}, \mathrm{pAS}_{3 \beta}\right)$ are unique, and code for novel SAA variants (see also Figs. 3 and 4). pAS $_{3 \alpha}$ is identical with the pAl sequence (Sipe et al., 1985; renamed ApoSAA1 $\alpha$ by Woo et al., 1987) with the exception of AAT (asparagine) instead of GAT (aspartic acid) in position 60. This amino acid substitution is also found in other SAA sequences [SAAg9 (Woo, 1986; Woo et al., 1987) and $\mathrm{pAS}_{3 \beta}$ and $\mathrm{pAS}_{8}$ (the present paper)]. The sequence of $\mathrm{pAS}_{3 \beta}$ differs from that of $\mathrm{pAS}_{3 \alpha}$ at position 57, with alanine in $\mathrm{pAS}_{3 \alpha}$ and with valine in $\mathrm{pAS}_{3 \beta}$, according to the designation given by Parmelee et al. (1982).

Clone $\mathrm{pAS}_{1}$ represents the $3^{\prime}$ segment (amino acid residues 54-104) and clone $\mathrm{pAS}_{4}$ represents the $5^{\prime}$ part (amino acid residues 1-54) of the pAl sequence. One silent nucleotide substitution, however, is present at position 78 coding for alanine (GCC instead of GCT). As all our 3' SAA cDNA clones contain the GCC codon in this position, the difference therefore cannot be explained as a cDNA cloning artifact. This nucleotide exchange, which has also been described by Kluve-Beckerman et al. (1986, 1988), may represent an allelic difference.

Clone $\mathrm{pAS}_{2}$ could be derived from the $3^{\prime}$ segment of the genomic clone SAAg9 (Woo et al., 1987), because it has an identical nucleotide sequence.

Clone $\mathrm{pAS}_{8}$, lacking the internal PstI site, is identical with the pSAA82 cDNA, renamed pSAA2 $\alpha$ (Kluve-Beckerman et al., $1986,1988)$. In addition, a truncated $5^{\prime}$ cDNA segment of $\mathrm{pAS}_{8}$ spanning 60 nucleotide residues from the $5^{\prime}$ untranslated region and the residues coding for the first 37 amino acid residues was obtained and designated $\mathrm{pAS}_{6}$.

Some of the isolated cDNA clones differ only by one base substitution. As the resulting amino acid exchangè have been 


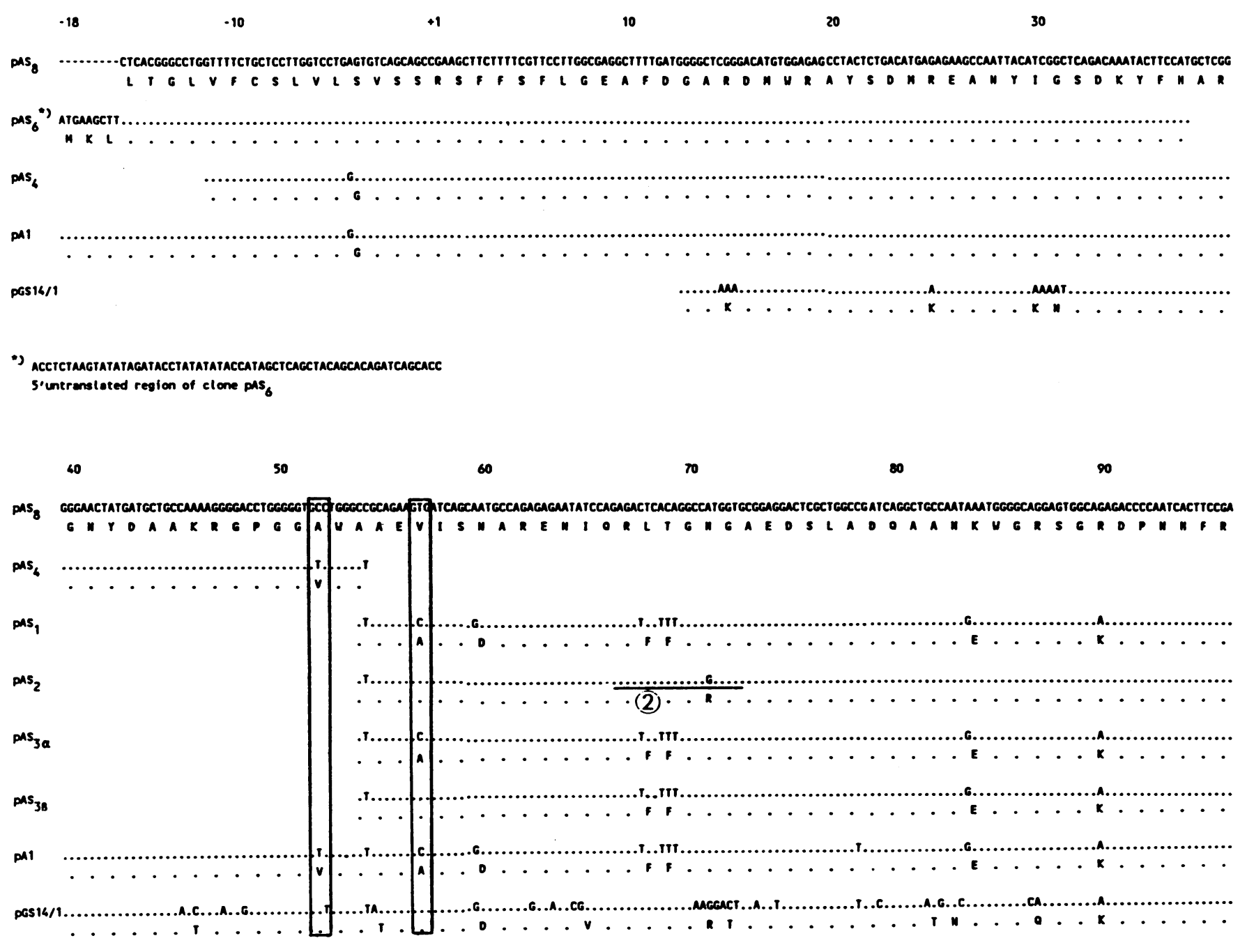

$100 \quad 104$

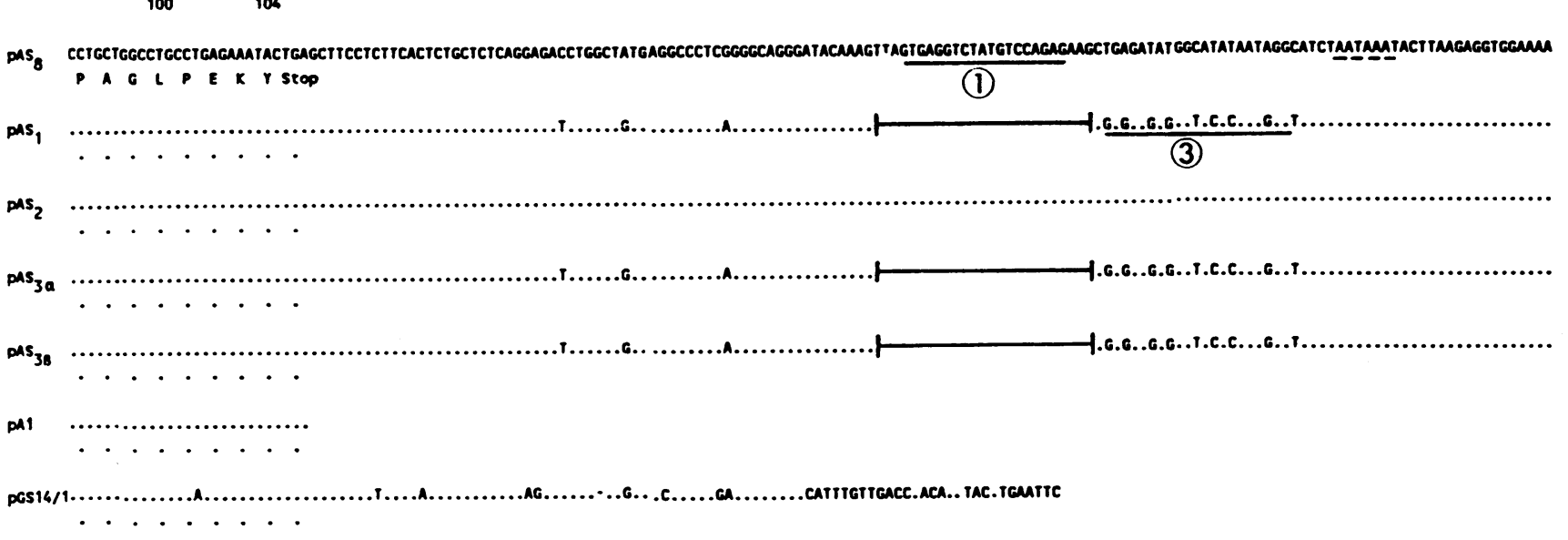

Fig. 2. Nucleotide sequences of analysed SAA cDNA clones and deduced amino acid sequences

The different clones were isolated from one acute-phase liver. Clones pAl (Sipe et al., 1985) and pGS14/1 (Sack \& Lease, 1986) are included for comparison. All 3' clones extend into the poly(A) tail. Sequences for synthesis of the oligonucleotides oAS ${ }_{2}$, oAS $_{1}$ and oAS ${ }_{8}$ are underlined. oAS 8 (1) and $\mathrm{OAS}_{1}$ (3) almost cover the unique 64-89 segment and the 90-112 segment of the $3^{\prime}$ untranslated region respectively. oAS $\mathrm{S}_{2}$ (2) is derived from a translated region of clone $\mathrm{pAS}_{2}$. A 25 -nucleotide-residue deletion in the $3^{\prime}$ untranslated region of clones $\mathrm{pAS}_{1}$, $\mathrm{pAS}_{3 \alpha}$ is designated by a bar, and the polyadenylation recognition site by a broken line. The amino acid residues 52 and 57 specific for the $\alpha$ - and $\beta$-forms of SAA polypeptides are boxed. 
Variant amino acid residues

23254143525357586066686971758490

Sletten \& Husby (1974) N R N D V W A I D O

Ein et al. (1972)

D R ${ }_{D}^{N}{ }_{D}^{N}$

Sletten et al. (1976)

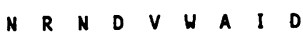

Levin et al. (1973)

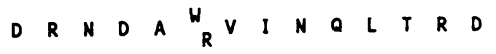

Moyner et al. (1980)

N R N $\quad D \quad V_{A} W_{R} A$ I $D$ E F F F H N

Sletten et al. (1983)

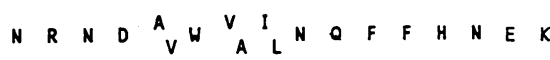

Parmelee et al. (1982)

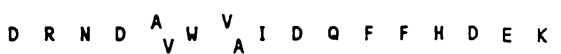

Fig. 3. Summary of SAA variants described at the protein level

$\mathrm{SAA}_{12}$ and AA-type amyloid fibril proteins are compared. The first five sequences are from AA proteins and the last two are from $\mathrm{SAA}_{12}$ proteins. Only the variant positions are listed. In some instances two amino acids residues have been identified at the same position, and both are stated.

found at the protein level (see Fig. 3), these variations are not due to a cloning artifact and represent individual gene transcripts.

On the basis of the $3^{\prime}$ untranslated region, our sequences fall into two groups (see Table 1): group I $\left(\mathrm{pAS}_{1}, \mathrm{pAS}_{3 \alpha}\right.$ and $\mathrm{pAS}_{3 \beta}$ ) has a $3^{\prime}$ untranslated region that differs from the sequence of group II $\left(\mathrm{pAS}_{2}\right.$ and $\left.\mathrm{pAS}_{8}\right)$ by a deletion of 25 nucleotide residues followed by a divergent segment of 23 nucleotide residues. This segment in $\mathrm{pAS}_{1}, \mathrm{pAS}_{3 \alpha}$ and $\mathrm{pAS}_{3 \beta}$ differs by nine bases from the analogous sequence found in $\mathrm{pAS}_{2}$ and $\mathrm{pAS}_{8}$. Interestingly, this dichotomy extends also to the coding region, in that group I corresponds closely to the sequence of pAl. Members within group II are virtually identical, but they differ from $\mathrm{pA} 1$ at positions 68, 69, 84 and 90 . The amino acid exchanges between pAl and $\mathrm{pAS}_{2} / \mathrm{pAS}_{8}$ include glutamic acid to lysine at position 84 and phenylalanine to threonine at position 69 . The other three exchanges are more conservative.

Two positions are found to be independent of the group I/II pattern. In position 60 the exchange of aspartic acid in pAl to asparagine is present in both groups. Another variable substitution concerns the $\alpha / \beta$ variability (Parmelee et al., 1982) at position 57 . Whereas in group I both valine ( $\beta$-variant) in pAS and alanine ( $\alpha$-variant) in $\mathrm{pAS}_{1}$ and $\mathrm{pAS}_{3 \alpha}$ were found, in group II ( $\mathrm{pAS}_{2}$ and $\mathrm{pAS}_{8}$ ) only the $\beta$-variant was present.

Finally, in order to be able to distinguish nucleotide sequences of group I from those of group II, oligonucleotide probes oAS and $\mathrm{oAS}_{8}$, specific for members of group I and II respectively, were synthesized as indicated in Fig. 2.

\section{Southern-blot analysis}

To examine the variability of SAA on the genomic level, the DNA of four individuals (K, LV, LR and JB) was digested with endonuclease TaqI, EcoRI, BglII or PstI and tested with 5' cDNA pAS $_{4}$ and $3^{\prime}$ cDNA pAS $_{1}$. As shown in Figs. 5(a) and 5(b), two strongly labelled bands and up to three weaker bands were reproducibly detected in each digest with both probes. Additional bands were observed in some individuals, indicating isotypic and/or allotypic SAA variations.

Both cDNA probes hybridized strongly with $2.0 \mathrm{~kb}$ and $4.0 \mathrm{~kb}$ TaqI fragments, whereas a $5.7 \mathrm{~kb}$ band was recognized less intensely. However, a $5.9 \mathrm{~kb}$ TaqI fragment hybridized only with the 5' cDNA clone (Fig. 5a). In addition, TaqI restriction revealed polymorphic fragments in two unrelated individuals $(\mathrm{K}$

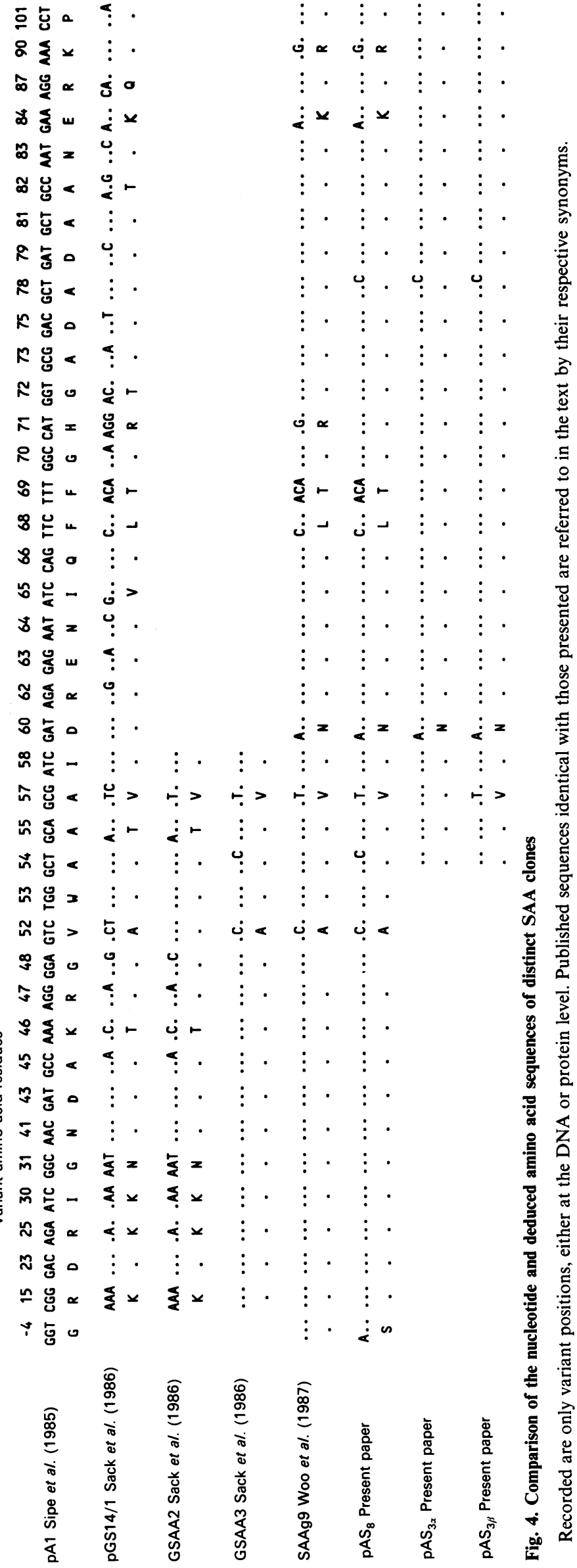


and $\mathrm{LV}$ ). An additional $3.0 \mathrm{~kb}$ fragment was recognized by both the $5^{\prime}$ and the $3^{\prime}$ SAA probes, and a $5.5 \mathrm{~kb}$ band was detected with the $3^{\prime}$ probe.

The EcoRI digest showed two strongly hybridizing bands $(11.5 \mathrm{~kb}$ and $11.0 \mathrm{~kb})$ that were recognized by both plasmid probes $\mathrm{pAS}_{1}$ and $\mathrm{pAS}_{4}$. Since the two oligonucleotides bound to different fragments, the $11.5 \mathrm{~kb}$ band detected with oAS (specific $_{2}$ for the translated region of clone $\mathrm{pAS}_{2}$; Fig. $5 d$ ), may contain the gene coding for $\mathrm{pAS}_{2}$, and the $11.0 \mathrm{~kb}$ band, which hybridized with $\mathrm{OAS}_{1}$ (specific for the short $3^{\prime}$ untranslated region of clones $\mathrm{pAS}_{1}, \mathrm{pAS}_{3 \alpha}$ and $\mathrm{pAS}_{3 \beta}$; Fig. 5c), could represent the genes coding for $\mathrm{pAS}_{1}, \mathrm{pAS}_{3 \alpha}$ and $\mathrm{pAS}_{3 \beta}$ (for sequence see Fig. 2). In

\section{Table 1. Synopsis of cloned SAA sequences}

Known SAA sequences are divided into three groups on the basis of nucleotide sequence homology in the coding and the $3^{\prime}$ untranslated region. Concerning the $\alpha / \beta$ variability see the text.

\begin{tabular}{|c|c|c|c|}
\hline & Clone & $\alpha / \beta$ & Reference \\
\hline Group I & $\begin{array}{l}\text { pAl (apoSAA1 } \alpha) \\
\text { pAS }_{1} \\
\text { pAS }_{3 \alpha} \\
\text { pAS }_{3 \beta}\end{array}$ & $\begin{array}{l}\alpha \\
\alpha \\
\alpha \\
\beta\end{array}$ & $\begin{array}{l}\text { Sipe et al. }(1985) \\
\text { Present paper } \\
\text { Present paper } \\
\text { Present paper }\end{array}$ \\
\hline Group II & $\begin{array}{l}\text { pSAA82 (pSAA2 } \alpha) \\
\text { SAAg9 } \\
\text { pAS }_{2} \\
\text { pAS }_{8}\end{array}$ & $\begin{array}{l}\beta \\
\beta \\
\beta \\
\beta\end{array}$ & $\begin{array}{l}\text { Kluve-Beckerman et al. } \\
(1986,1988) \\
\text { Woo et al. }(1987) \\
\text { Present paper } \\
\text { Present paper }\end{array}$ \\
\hline Group III & $\mathrm{pGS} 14 / 1$ & $\beta$ & Sack \& Lease (1986) \\
\hline
\end{tabular}

addition, a $1.3 \mathrm{~kb}$ EcoRI band was only recognized with the 3' cDNA probe pAS $_{1}$ (Fig. $5 b$ ).

The $B g l \mathrm{II}$ digest showed a $4.5 \mathrm{~kb}$ and a $12.5 \mathrm{~kb}$ band that were recognized by both probes. Two additional fragments, a $0.7 \mathrm{~kb}$ and a $6.0 \mathrm{~kb}$ band, only hybridized with the $3^{\prime}$ probe (Fig. $5 b$ ).

The PstI restriction pattern is more complex, as might be expected given the variant PstI restriction site in the cDNA clones. The $3.0 \mathrm{~kb}$ Pst I fragment may represent the gene coding for $\mathrm{pAS}_{8}$ without the internal PstI site, because it was recognized by both probes in all four individuals. A $1.4 \mathrm{~kb}$ and a $1.8 \mathrm{~kb}$ band hybridized only with the $5^{\prime}$ probe (Fig. $5 a$ ), whereas a $2.3 \mathrm{~kb}$ fragment was detected with the $3^{\prime}$ probe (Fig. $5 b$ ). A single polymorphic $4.9 \mathrm{~kb}$ fragment recognized by both probes and identified in only one individual (LV) is indicative of an allotypic SAA variant.

\section{Northern-blot analysis}

The expression of SAA genes was investigated by Northernblot analysis, with separation of the mRNA by electrophoresis on a $1.2 \%$ agarose gel. The hybridization signal in mRNA isolated from acute-phase liver was always strong and broad, indicating a very large amount of SAA mRNA pesent (see Fig. 6 , lane a). We have previously shown that SAA transcripts can only be detected in RNA isolated from acute-phase liver. No mRNA was detectable in normal liver biopsies (Schwaeble et al., 1987). Short exposure to X-ray film of the blot demonstrated the presence of more than one mRNA species. Fractionation of the RNA by electrophoresis on a polyacrylamide gel having a higher resolution showed three distinct bands of approx. 530, 600 and 650 nucleotide residues (Fig. 6, lanes b-e).

With the $3^{\prime}$ cDNA pAS ${ }_{1}$ as probe, the two larger mRNAs gave roughly the same strong signal, whereas the 530-nucleotide transcript hybridized more weakly (Fig. 6, lane b). (a)

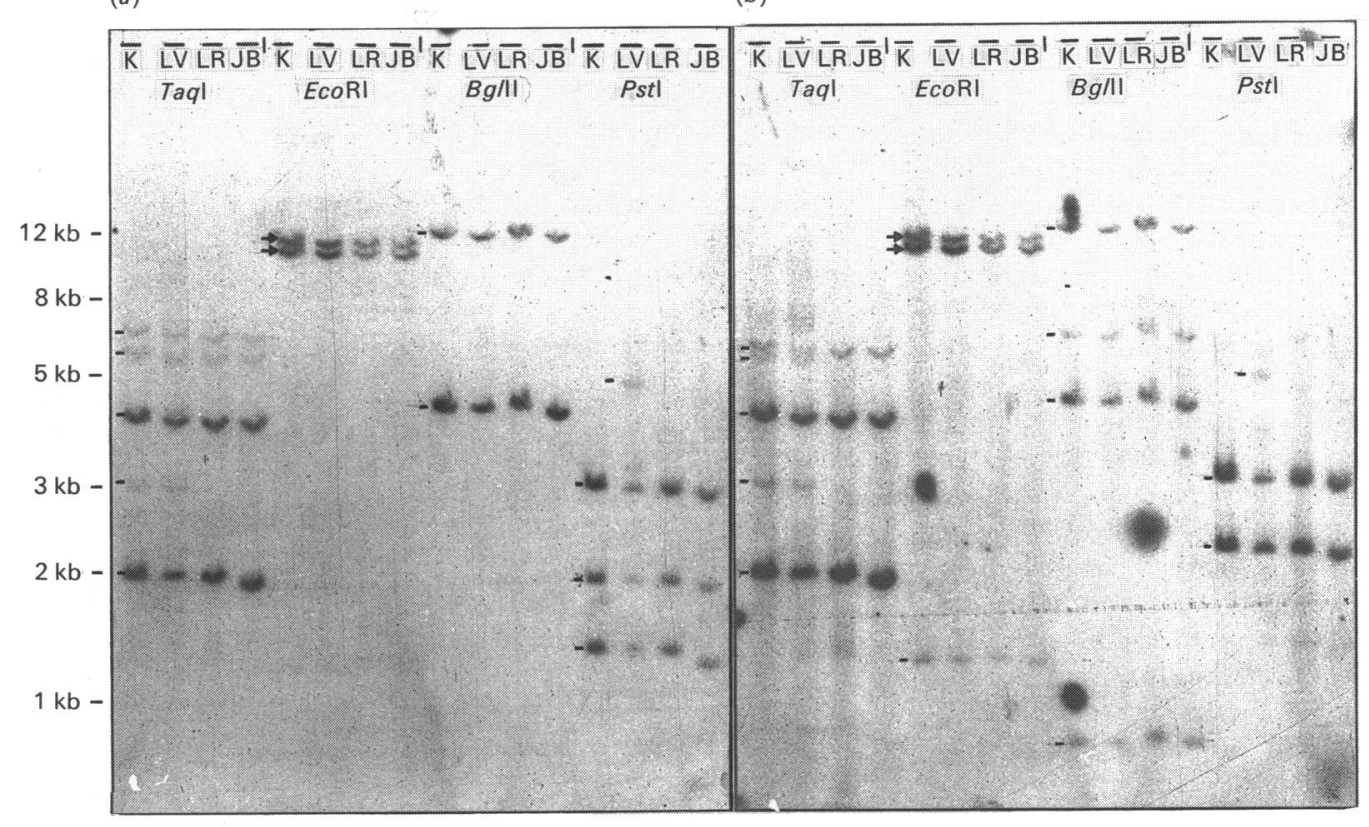

(c) $\quad(d)$

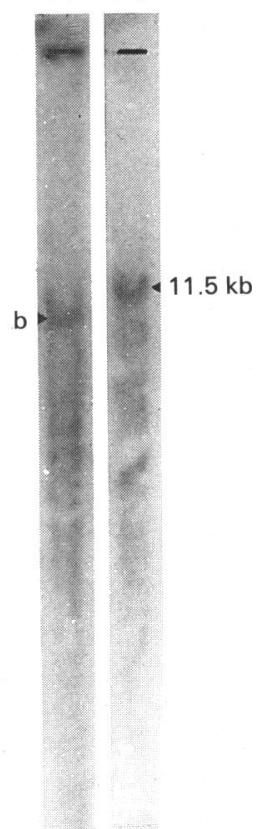

Fig. 5. Genomic Southern-blot analysis

Analysis of restriction-fragment length polymorphism of DNA isolated from four individuals (K, LV, LR and JB). DNA of each was digested with four different restriction enzymes, separated by electrophoresis on a $0.7 \%$ agarose gel, transferred to nylon membrane and hybridized with two probes: the $5^{\prime}$ probe $\operatorname{pAS}_{4}(a)$ and the $3^{\prime}$ probe $\mathrm{pAS}_{1}(b)$. All relevant bands are labelled by a dash on the left-hand side. The $11.5 \mathrm{~kb}$ and $11.0 \mathrm{~kb} E c o \mathrm{RI}$ fragments are denoted by arrows. Both fragments hybridize equally with plasmid probes but differentially with the oligomers. oAS ${ }_{2}$ recognized the $11.5 \mathrm{~kb}$ fragment $(d)$ and $\mathrm{oAS}$ the $11.0 \mathrm{~kb}$ band $(c)$. For sequences of oligonucleotide probes see Fig. 2. 


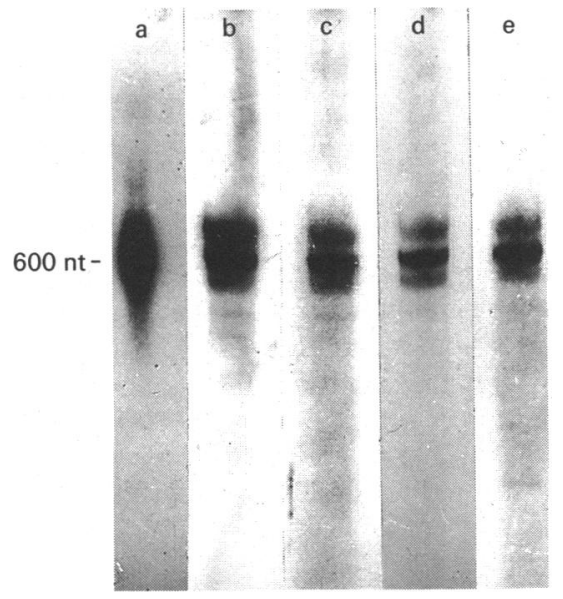

Fig. 6. Northern-blot analysis

RNA from a human acute-phase liver was separated by electrophoresis on a $1.2 \%$ agarose gel (lane a) or on a urea/polyacrylamide gel (lanes b-e), and hybridized with plasmid probe pAS (lanes a and b), oligomer oAS (lane c), oAS, (lane d) and $\mathrm{oAS}_{8}$ (lane e). For sequences of oligonucleotides see Fig. 2. Abbreviation: nt, nucleotide residues.

Unexpectedly, the three oligonucleotides $\left(\mathrm{oAS}_{1}, \mathrm{oAS}_{2}\right.$ and $\mathrm{oAS}_{8}$ ) hybridized to each of the three mRNA bands, and no clear difference could be found in their hybridization intensities. In contrast with the hybridization signal obtained with the $3^{\prime}$ plasmid probe $\mathrm{pAS}_{1}$, the corresponding oligomer $\mathrm{oAS}_{1}$ and also $\mathrm{oAS}_{2}$ and $\mathrm{oAS}_{8}$ gave the strongest signal with the 600-nucleotide transcript. The large SAA mRNA species of 650 nucleotide residues may therefore contain also other transcripts lacking the 3 ' untranslated sequences detected with our oligonucleotide probes.

\section{DISCUSSION}

A minimum of five different transcripts can be deduced from six different mRNAs identified from one organ. This is the largest number of distinct SAA variants reported from one single individual to date. The finding of multiple transcripts in the acute-phase-liver cDNA library of one individual strongly indicates that in man all these variants are translated during an acute phase. This assumption corroborates data reported for the mouse system by Meek \& Benditt (1986) and Lowell et al. (1986).

In general, our cDNA sequences are more closely related to the sequences encoded by pA1, SAAg9 and pSAA82 than to the other type of variants represented by clone pGS14/1, which was isolated with the use of a mouse clone pRS48 (Stearman et al., 1982). The use of the pAl cDNA as screening probe may have been responsible for the preferential isolation of more homologous cDNA clones, since only strongly hybridizing colonies were selected (see also discussion of the Southern-blot analysis and Figs. $5 a$ and $5 b$ ). The five clones presented covering the 3' translated region fall into two distinct groups, based on identical $3^{\prime}$ untranslated segments (group I, $\mathrm{pAS}_{1}$ and $\mathrm{pAS}_{3 \alpha}, \mathrm{pAS}_{3 \beta}$; group II, $\mathrm{pAS}_{2}$ and $\mathrm{pAS}_{8}$; see Table 1). We assume these specific $3^{\prime}$ segments to be related to a possible post-transcriptional regulation of SAA gene expression. Since this group I/II variability extends to the coding region, two separate groups of genes should be postulated.

One DNA segment (coding for amino acid residues 33-45) is constant in all human SAA sequences, and no difference is found at the protein level when compared with different species, indicating an important function (Hermodsen et al., 1972; Skinner et al., 1974; Gorevic et al., 1978; Waalen et al., 1980; Parmelee et al., 1982; Sletten et al., 1983; Hoffman et al., 1984; Lowell et al., 1986; Dwulet et al., 1988), and is consistent with interspecies cross-reactivity (Linke et al., 1984).

On the basis of the degree of sequence homology, the known human SAA sequences fall into three groups: group I and II (mentioned above), and a third group represented by the clone pGS14/1 (see Table 1). From sequence comparison we assume the following evolutionary relation: after duplication of an ancient gene, an ancestral pA1 and an ancestral pGS14/1 gene were formed. A more recent split of a pAl protogene resulted in the two groups of pA1- and pSAA82-like genes. Comparison of mouse SAA variants with the human analogues did not disclose correspondence of any of the former to the latter. One therefore can assume a parallel evolution of the mouse and the human SAA genes, probably beginning at early Tertiary times. A similar evolutionary tree of the mouse SAA gene family has been proposed by Lowell et al. (1986).

The identification of a minimum of five distinct SAA transcripts in one human acute-phase liver supports the assumption of a multigene family coding for many SAA polypeptides. A minimal number of three loci (isotypes) could explain the cDNA spectrum in our study of a heterozygous individual; each locus then would show considerable polymorphism.

Considering the variation of the SAA sequences, Southernblot analysis showed only few bands. Therefore SAA genes appear to be similar, and the variations, mostly in the $3^{\prime}$ half of the genes, do not extend to the flanking region. The more weakly hybridizing fragments (TaqI, 5.7 and $5.9 \mathrm{~kb}$;EcoRI, $1.3 \mathrm{~kb}$; $B g l I I, 6.0 \mathrm{~kb}$ band) might represent SAA genes that have less sequence similarity to the probes used in our analysis. As bands of similar size have been described by Sack et al. (1989) using a probe derived from pGS14/1, we assume that the TaqI fragments of 5.7 and $5.9 \mathrm{~kb}$ and the $B g I I I$ band of $6.0 \mathrm{~kb}$ code for group III homologous gene fragments. No weakly hybridizing fragments are detected in the DNA digested with PstI. Thus with respect to this restriction enzyme the divergent SAA sequences detected with the probe used by Sack et al. (1989) and our probe are similar with the exception of the $1.4 \mathrm{~kb}$ PstI band in Fig. 5(a). Those authors also used a group-II-derived genomic probe in Southern-blot analysis but did not detect the $1.4 \mathrm{~kb}$ Pst I band. As their probe corresponding to our $5^{\prime}$ probe contains mostly intronic sequences, its use might have biased the hybridization pattern to the detection of more homologous genes.

All polymorphic fragments revealed by Southern-blot analysis in two individuals (TaqI, 3.0 and $5.5 \mathrm{~kb} ;$ Pst I, $4.9 \mathrm{~kb}$ band; Figs. $5 a$ and $5 b ; \mathrm{K}$ and $\mathrm{LV}$ ) are presumably derived from group-IIIlike genes and are indicative of isotypes and allotypes. However, only isolation of the entire region coding for SAA genes will allow the exact identification of isotypic and allotypic sequences.

The results of Northern-blot analysis show that presumably all members of the SAA multigene family are expressed during the acute-phase induction. SAA transcripts were resolved into three major mRNA species. The significance of the three SAA mRNA species might be explained by differences in the length of the poly(A) tail. Size alterations of the $\alpha_{1}$-acid glycoprotein mRNA have already been shown in rat during the acute-phase reaction, and these were due to a stepwise trimming of the poly(A) tail, resulting in a few differently sized mRNA species (Shiels et al., 1987). In addition, the length of the poly(A) tail is important for the stability of mRNAs (Zeevi et al., 1982). Thus the 650nucleotide-residue transcript, with presumably the longest poly(A) tail, might be the most stable SAA mRNA.

The finding that $\mathrm{SAA}_{12}$ polypeptides are coded by a gene family and that presumably most of the SAA genes are turned on 
during acute-phase reactions underscore the necessity for continuing investigation on a possible differential function of these molecules. In addition, like other members of multigene families, e.g. the MHC antigens (Todd et al., 1988), it is conceivable that some of the genes might be polymorphic, and specific amino acid substitutions could result in additional amyloidogenic SAA SA $_{12}$ precursor proteins (Gorevic et al., 1976).

Finally, the different cDNA clones presented in this study can be used to characterize available monoclonal antibodies or to generate variant-specific antibodies. These reagents may recognize SAA variants that play an important role in the pathogenesis of AA-type amyloidosis.

\section{Note added in proof (received 2 April 1990)}

After this paper was submitted, the complete sequence of the human genomic SAA gene pGS 14/1 was reported by Sack \& Talbot (1989), which corresponds to the 'SAA-like' autocrine collagenase inducer of the rabbit reported by Brinkerhoff $e t$ al. (1989).

We express our appreciation to Dr. J. D. Sipe (Department of Biochemistry, Boston University School of Medicine, Boston, MA, U.S.A.) for providing the cDNA clone pAl, K. Stanley (Heidelberg, Germany) for the liver cDNA expression library, R. Mertz (Munich, Germany) for synthesis of the three oligonucleotides, and Ms. U. Kunert, Ms. A. Rail and Ms. A. Kerling for expert technical help. This study was supported by the Deutsche Forschungsgemeinschaft, Sonderforschungsbereich 207, Munich (Grant G8). A. S. was a recipient of a postdoctoral fellowship awarded by the Boehringer Ingelheim Fonds (Germany). We thank Dr. Sack (The Johns Hopkins Hospital, Baltimore, MD, U.S.A.) for kindly reading the manuscript.

\section{REFERENCES}

Bausserman, L. L., Herbert, P. N. \& McAdam, K. P. W. J. (1980) J. Exp. Med. 152, 641-656

Benditt, E. P. \& Eriksen, N. (1977) Proc. Natl. Acad. Sci. U.S.A. 74, 4025-4028

Benditt, E. P., Hoffman, J. S., Eriksen, N. \& Walsh, K. A. (1982) Ann. N.Y. Acad. Sci. 389, 183-189

Brinkerhoff, C. E., Mitchell, T. I., Karmilowicz, M. J., Kluve-Beckerman, B. \& Benson, M. D. (1989) Science 243, 655-657

Collins, M. L. \& Hunsaker, W. R. (1985) Anal. Biochem. 151, 211-215

Dwulet, F. E., Wallace, D. K. \& Benson, M. D. (1988) Biochemistry 27, $1677-1682$

Ein, D., Kimura, S. \& Glenner, G. G. (1972) Biochem. Biophys. Res. Commun. 46, 498-500

Feinberg, A. P. \& Vogelstein, B. (1983) Anal. Biochem. 132, 6-13

Geliebter, J., Zeff, R. A., Schulze, D. H., Pease, L. R., Weiss, E. H., Mellor, A. L., Flavell, R. A. \& Nathenson, S. G. (1986) Mol. Cell. Biol. 6, 645-652

Glenner, G. G. (1980a) N. Engl. J. Med. 302, 1283-1292

Glenner, G. G. (1980b) N. Engl. J. Med. 302, 1333-1343

Gorevic, P. D., Rosenthal, C. J. \& Franklin, E. C. (1976) Clin. Immunol. Immunopathol. 6, 83-92

Gorevic, P. D., Levo, Y., Frangione, B. \& Franklin, E. C. (1978) J. Immunol. 121, 138-140

Hermodsen, M. A., Kuhn, R. W., Walsh, K. A., Neurath, H., Eriksen, N. \& Benditt, E. P. (1972) Biochemistry 11, 2934-2938

Hoffman, J. S., Ericsson, H. L., Eriksen, N., Walsh, K. A. \& Benditt, E. P. (1984) J. Exp. Med. 159, 641-646

Kluve-Beckerman, B., Lang, G. L. \& Benson, M. D. (1986) Biochem. Genet. 24, 795-803

Received 28 June 1989/14 November 1989; accepted 24 November 1989
Kluve-Beckerman, B., Dwulet, F. E. \& Benson, M. D. (1988) J. Clin. Invest. 82, 1670-1675

Levin, M., Pras, M. \& Franklin, E. C. (1973) J. Exp. Med. 138, 373-380

Linke, R. P. (1980) in Amyloid and Amyloidosis (Glenner, G. G., Costa, P. P. \& de Freitas, A. F., eds.), pp. 131-319, Excerpta Medica, Amsterdam, Oxford and Princeton

Linke, R. P., Sipe, J. D., Pollock, P. S., Ignaczak, T. F. \& Glenner, G. G. (1975) Proc. Natl. Acad. Sci. U.S.A. 72, 1472-1476

Linke, R. P., Hol, P. R., Guyes, E., Geisel, O., Nathrath, W. B. J. \& Trautwein, G. (1984) J. Comp. Pathol. 94, 339-356

Lowell, C. A., Potter, D. A., Stearman, R. S. \& Morrow, J. F. (1986) J. Biol. Chem. 261, 8442-8452

Maniatis, T., Fritsch, E. F. \& Sambrook, J. (1982) Molecular Cloning: A Laboratory Manual, Cold Spring Harbor Press, Cold Spring Harbor Marhaug, G. \& Husby, G. (1981) Clin. Exp. Immunol. 45, 97-106

Meek, R. L. \& Benditt, E. P. (1986) J. Exp. Med. 164, 2006-2017

Moyner, K., Sletten, K., Husby, G. \& Natvig, J. B. (1980) Scand. J. Immunol. 11, 549-554

Parmelee, D. C., Titani, K., Ericsson, L. H., Erikson, N., Benditt, E. P. \& Walsh, K. A. (1982) Biochemistry 21, 3298-3303

Sack, G. H. \& Lease, J. J. (1986) in Amyloidosis (Glenner, G. G., Osserman, E. F., Benditt, E. P., Calkins, E., Cohen, A. S. \& ZuckerFranklin, D., eds.), pp. 61-68, Plenum Press, New York and London Sack, G. H. \& Talbot, C. C. (1989) Gene 84, 509-515

Sack, G. H., Lease, J. J. \& De Berry, C. S. (1986) Protides Biol. Fluids 34, 327-330

Sack, G. H., Talbot, C. C., Seuanez, H., Jr. \& O’Brien, S. J. (1989) Scand. J. Immunol. 29, 113-119

Sanger, F., Nicklen, S. \& Coulson, A. R. (1977) Proc. Natl. Acad. Sci. U.S.A. 74, 5463-5467

Schwaeble, W., Zwirner, J., Schulz, T. F., Linke, R. P., Dierich, M. P. \& Weiss, E. H. (1987) Eur. J. Immunol. 17, 1485-1489

Shiels, B. R., Northemann, W., Gehring, M. R. \& Fey, G. H. (1987) J. Biol. Chem. 262, 12826-12831

Sipe, J. D., Colten, H. R., Goldberger, G., Edge, M. D., Tack, B. F., Cohen, A. S. \& Whitehead, A. S. (1985) Biochemistry 24, 2931-2936

Skinner, M., Cathcart, E. S. \& Benson, M. D. (1974) J. Exp. Med. 140, 871-876

Skogen, B., Sletten, K., Lea, T. \& Natvig, J. B. (1986) in Amyloidosis (Glenner, G. G., Osserman, E. F., Benditt, E. P., Calkins, E., Cohen, A. S. \& Zucker-Franklin, D., eds.), pp. 11-18, Plenum Press, New York and London

Sletten, K. \& Husby, G. (1974) Eur. J. Biochem. 41, 117-125

Sletten, K., Husby, G. \& Natvig, J. B. (1976) Biochem. Biophys. Res. Commun. 69, 19-25

Sletten, K., Mahaug, G. \& Husby, G. (1983) Biol. Chem. Hoppe-Seyler 364, 1039-1046

Stanley, K. K. \& Luzio, J. P. (1984) EMBO J. 3, 1429-1434

Stearman, R. S., Lowell, C. A., Pearson, W. R. \& Morrow, J. F. (1982) Ann. N.Y. Acad. Sci. 389, 106-115

Steinkasserer, A., Weiss, E. H. \& Linke, R. P. (1988) Abstr. Eur. Immunol. Meet. 9th 145

Todd, J. A., Acha-Orbea, H., Bell, J. I., Chao, N., Fronek, Z., Jakob, C. O., McDermott, M., Sinha, A. A., Timmerman, L., Steinman, L. \& McDevitt, H. O. (1988) Science 240, 1003-1009

Waalen, K., Stetten, K., Husby, G. \& Nordstoga, K. (1980) Eur. J. Biochem. 104, 407-412

Westermark, P. (1982) Biochim. Biophys. Acta 701, 19-23

Woo, P. (1986) in Amyloidosis (Marrink, J. \& van Rijswijk, M. H., eds.), pp. 135-139, Martinus Nijhoff, Dordrecht and Amsterdam

Woo, P., Sipe, J. D., Dinarello, C. A. \& Colten, H. R. (1987) J. Biol Chem. 262, 15790-15795

Yamamoto, K., Shiroo, M. \& Migita, S. (1986) Science 232, 227-229

Yamamoto, K., Goto, N., Kosaka, J., Shiro, M., Yene, Y. \& Migita, S. (1987) J. Immunol. 139, 1683-1688

Zeevi, M., Nevins, J. R. \& Darnell, J. E. (1982) Mol. Cell. Biol. 2, $517-525$ 